\title{
The Rights of Each Wife in the Division of Community Property in Polygamous Marriage According to Law Number 1 of 1974 Concerning Marriage
}

\author{
Nurul Maulidah; Thohir Luth; Iwan Permadi; Masruchin Ruba'i \\ Postgraduate Program in Law, Universitas Brawijaya, Indonesia
}

http://dx.doi.org/10.18415/ijmmu.v6i1.621

\begin{abstract}
This study aims to analyze the norms that all wives have the same rights over community property obtained since the marriage took place as the norm in Article 65 paragraph (1) letter c of Law number 1 of 1974 concerning Marriage. Therefore, this will get answers to the rights of each wife to community property in the division of community property in polygamous marriage. This research includes the type of legal research. The research method is based on the nature of legal science whose object is the norm. Legal research assesses legal norms so that it is normative. A man and woman before marriage each have complete rights to their property. After binding themselves to a marriage institution, there are norms governing their rights to property ownership. Community property in a marriage is realized by the effort of husband and wife; however, the capital can also come from separate property or gifts from each husband and wife which are manifested into property in marriage. Determination of community property in polygamous marriages is only based on marriage in which each wife can ignore the rights of another wife.
\end{abstract}

Keywords: Law; Polygamous Marriage; Property

\section{Introduction}

The provision of guarantee, protection and legal certainty in the field of marriage is regulated in Law Number 1 of 1974 concerning Marriage ${ }^{1}$. The law adheres to the principle of monogamy ${ }^{2}$; the principle requires that in a marriage a man may only marry with a wife and a wife may only do marriage

\footnotetext{
${ }^{1}$ State Gazette of the Republic of Indonesia of 1974 number 1, supplement to State Gazette of the Republic of Indonesia number 3019. The definition of marriage is affirmed in Article 1 that "marriage is an inner and outer bond between a man and a woman as a husband and wife who aim to form a happy and eternal household based on the God Almighty". In accordance with the purpose of the marriage, the husband and wife in marriage are needed to help each other and complete in order to achieve spiritual and material welfare. See General Explanation number 4 letter a of Explanation of Law number 1 of 1974 concerning Marriage). See also Sonny Dewi Judiasih, Harta Benda Perkawinan (Marriage Property), (Bandung: Refika Aditama, 2015), page 23.

${ }^{2}$ General Explanation number 4 letter $\mathrm{c}$ of Law number 1 of 1974 concerning Marriage.
} 
with a man ${ }^{3}$. However, the principle of monogamy within the Law is not absolute because it still provides an opportunity for a husband to marry more than a wife or is known as polygamous marriage ${ }^{4}$.

In polygamous marriage, a husband has more than one wife, even up to four wives ${ }^{5}$. The marriage will also obtain community property; i.e. assets obtained during polygamous marriage. Such a situation has the potential to create conflict between them in terms of polygamous marriage itself and in terms of community property. Therefore, the conditions for justice in polygamous marriage are very necessary. According to Abbas Mahmud Al-Aqqad, a good marriage law is one that guarantees and maintains the essence of marriage to deal with any situation that occurs or that may occur ${ }^{6}$; including the settlement of the possibility of community property disputes in polygamous marriages. Therefore, the procedures, reasons, and conditions for conducting polygamous marriages are regulated in Law number 1 of 1974 concerning Marriage. A husband who is going to do polygamous marriage makes a proposal to the court ${ }^{7}$. The court gives permission if the polygamy permit proposal fulfills the specified reasons ${ }^{8}$ and conditions; among others, "there is a guarantee that the husband will be fair to their wives and children"?

According to Imam Syafii, justice is a condition in polygamous marriage and justice regarding physical matters ${ }^{10}$. Mustafa al-Sibai argues that justice needed in polygamous marriage includes material justice, such as housing, clothing, food, and things that are material needs ${ }^{11}$. A husband who wants to do a polygamous marriage must at least fulfill two conditions. First is the ability of sufficient funds to finance various needs related to the increasing number of wives. The second is the obligation to treat all wives fairly. Every wife must be treated equally in fulfilling marital rights including rights in terms of property $^{12}$.

\section{Research Method}

\section{Type of Research \\ a. Sources of Legal Material}

\footnotetext{
${ }^{3}$ Article 3: (1) "Principally, in a marriage, a man may only have a wife. A wife can only have a husband". (2) "Courts can give permission to a husband to have more than one wife if desired by the parties". See also General Explanation number 4 letter c as follows: "This Law adheres to the principle of monogamy". "Only if it is desired by related person. Since the law and religion permit it, a husband can marry more than a wife. Even though this is desired by related parties, it can only be carried out if certain conditions are met and decided by the Court".

${ }^{4}$ The word polygamy comes from Greek, poly or polus which means a lot and gamein or gamos which means mating or marriage. Literally, polygamy means a marriage that is more than one, both male and female. A. Hafizh Anshari Az., et al, Ensiklopedi Hukum Islam (Encyclopedia of Islamic Law), (Jakarta: PT Ichtiar Baru Van Hoeve, 1996), page 107.

${ }_{6}^{5}$ Al-Quran Surah an-Nisâ (4) verse 3.

${ }^{6}$ Abbas Mahmud al-Aqqad, Falsafah al-Quran (Al-Quran Philosophy), (Cairo, Egypt: Dar al-Hilal, 1985), page 84.

${ }^{7}$ Article 3, Article 4, and Article 5 of Law Number 1 of 1974 concerning Marriage in conjunction with Article 40 of Government Regulation number 9 of 1975 concerning Implementation of Law Number 1 of 1974 concerning Marriage.

${ }^{8}$ Article 4 paragraph (2): "The court referred to in paragraph (1) of this article only grants permission to a husband who will have more than one wife if":

a. "the wife cannot carry out her obligations as a wife";

b. "the wife has a disability or an incurable disease";

c. "wife cannot give offspring."

9 "To submit a proposal to the Court, as referred to in Article 4 paragraph (1) of this Law, the following are the conditions that must be met":

a. "the agreement from the wife/ wives";

b. "certainty that the husband is able to guarantee the needs of the lives of his wives and children"; and "guarantee that husband will be fair to his wives and children".

${ }^{10}$ Khoirudin Nasution, Riba dan Poligami: Sebuah Studi atas Pemikiran Muhammad Abduh (Usury and Polygamy: A Study of Muhammad Abduh's Thought), (Jakarta: Pustaka Pelajar, 1996), page 103-105.

${ }^{11}$ Mostly, Islamic jurists argue that qualitative justice is very difficult to realize. According to Abdurrrahman al-Jaziri, equating rights to sexual needs and affection among wives is not an obligation in polygamous marriage, because humans will not be able to do justice in sharing love and that is very instinctive. Abd. Al-Rahman Al Jaziri, Kitab al Fiqh 'ala al-Madzhib al-'Arba'ah, (Egypt, al-Maktabah al-Tijariyayah, 1969), page 239.

${ }^{12}$ Abd. Rahman Doi, Penjelasan Lengkap Hukum-Hukum Allah (Syariah) (A Complete Explanation of God's Laws (Sharia)), (Jakarta: Rajawali Press, 2002), page 192.
} 
The sources of legal material in this study are primary and secondary legal materials. Primary legal material is a legal material that is "authoritative" which means that it has the authority and consists of legislation, official records or deeds in the making of legislation, or court decisions ${ }^{13}$. The basic norm in this study is the 1945 Constitution of the Republic of Indonesia after the fourth amendment. To support this research, it uses the legislation that includes:

- Law number 48 of 2009 concerning Judicial Power (State Gazette of the Republic of Indonesia of 2009 number 157, supplement to the State Gazette of the Republic of Indonesia number 5076);

- Law number 1 of 1974 concerning Marriage (State Gazette of the Republic of Indonesia of 1974 number 1, supplement to the State Gazette of the Republic of Indonesia number 3019);

- Law number 12 of 2011 concerning Establishment of Legislation (State Gazette of the Republic of Indonesia of 2011 number 82, supplement to the State Gazette of the Republic of Indonesia number 5234);

- Law number 39 of 1999 concerning Human Rights (State Gazette of the Republic of Indonesia of 1999 number 165, supplement to the State Gazette of the Republic of Indonesia number 3886);

- Law number 7 of 1989 concerning the Religious Courts (State Gazette of the Republic of Indonesia of 1989 number 73, supplement to the State Gazette of the Republic of Indonesia number 3316);

- Law number 3 of 2006 concerning changes to Law number 7 of 1989 concerning Religious Courts (State Gazette of the Republic of Indonesia of 2006 number 22, supplement to the State Gazette of the Republic of Indonesia number 4461);

- Law number 50 of 2009 concerning the second changes to Law number 7 of 1989 concerning Religious Courts (State Gazette of the Republic of Indonesia of 2009 number 159, supplement to the State Gazette of the Republic of Indonesia number 5078);

- Government Regulation number 9 of 1975 concerning Implementation of Law number 1 of 1974 (State Gazette of the Republic of Indonesia of 1975 number 12, supplement to the State Gazette of the Republic of Indonesia number 3050).

Secondary legal material is "all publications about law that are not official documents including textbooks, legal dictionaries, legal journals"14, opinions of scholars, legal cases, results of seminars, workshops, symposiums, and sources of legal material in the form of publication using internet media relating to research material.

\section{Legal Material Collection Technique}

Collection of legal materials was carried out by searching to obtain relevant legal materials to the problem that will be answered in this study; i.e. tracing the norms that govern the division of community property in polygamous marriage and analyzing them in depth so that they can answer the research problem. Legal materials that had been obtained will be recorded, edited, studied, and the conclusion will be drawn. Furthermore, the legal materials were collected, compiled, grouped, and examined according to the research problem. The processing of legal materials was carried out by selecting and sorting the existing legal materials as needed to answer the problem in this study.

\section{Analysis of Legal Material}

The next step of the research is to analyze the primary and secondary legal materials. Analysis of legal material in this study was carried out using analytical prescriptive; i.e. analyzing, understanding,

\footnotetext{
${ }^{13}$ Peter Mahmud Marzuki, Op.Cit., page 181.

${ }^{14}$ Ibid., page 141-163.
} 
explaining the facts experienced or found and continued by giving the expected answer to those facts. Thus, this research is expected to produce prescriptions about what should be the essence of legal research that adheres to the character of law as an applied science ${ }^{15}$. The results of the analysis using legal logic, legal arguments, and legal principles will produce conclusions as answers to the research problems that must be answered.

\section{Norms for Division of Community Property in Polygamous Marriage}

\section{Norms of Community Property}

The ontological basis of Law Number 1 of 1974 concerning Marriage is to provide protection and guarantee the rights and position of wives in marriage. The law regulates the rights and obligations of husband and wife ${ }^{16}$, and regulates that the position of husband and wife in marriage is balanced in carrying out legal acts ${ }^{17}$ as stated in Article 31 of Law Number 1 of 1974 concerning Marriage as follows:

a. "The rights and position of the wife are balanced with the rights and position of the husband in domestic life and the association of living together in the community."

b. "Each party has the right to carry out legal actions."

c. "The husband is the head of the household and the wife is the mother of the household/ housewife." Regulation on the rights of husband and wife regarding marital property listed in Article 35, Article 36, and Article 37 of Law number 1 of 1974 concerning Marriage including Chapter VII which regulates "Property in Marriage" as follows ${ }^{18}$ :

Article 35

(1) "Property acquired during marriage becomes community property".

(2) "The separate property of each husband and wife and the property acquired by each of them as gift or inheritance are under their respective control as long as the parties do not determine otherwise".

Article 36

(1) "Regarding community property, a husband or wife may act on the agreement of both parties".

(2) "Regarding separate property from husband and wife, each has the full right to carry out legal actions regarding his/her own property".

Article 37

"If the marriage ends because of divorce, community property is regulated according to their respective laws."

The norms in Article 35 and Article 36 of Law number 1 of 1974 concerning Marriage classify property in marriage and control of this property as follows:

\footnotetext{
${ }^{15}$ Peter Mahmud explained that legal science has a character as a prescriptive and applied science. As a prescriptive science, law studies the purpose of law, the values of justice, the validity of legal rules, legal concepts, and legal norms. As an applied science, legal science sets standards for procedures, provisions, and signs in implementing the rule of law, Peter Mahmud Marzuki, 2005, Penelitian Hukum (Legal Research), (Jakarta: Prenada Media, 2005), page 22.

16 "Rights are things that are owned or can be owned by a husband or wife that they obtain from the marriage. This right can be abolished if the rightful person is willing if his/her rights are not fulfilled or paid by another party. In addition, obligations are things that must be carried out or held by one husband or wife to fulfill the rights of the other party". Umar Said, Hukum Islam Indonesia, Tanggung Jawab Suami Istri dalam dan Pasca Perkawinan (Indonesian Islamic Law, Responsibilities of Husband and Wife in/ and after Marriage), (Surabaya: CV Cempaka, 1996), page 1.

${ }^{17}$ R. Subekti and R. Tjitrosudibyo, Kitab Undang-Undang Hukum Perdata dengan Tambahan Undang-Undang Pokok Agraria dan Undangundang Perkawinan (The Civil Code in addition to the Basic Agrarian Law and Marriage Law), 18 ${ }^{\text {th }}$ Edition, (Jakarta: Pradnya Paramita,1984), 547-548.
} 
(i) Community property is property acquired during marriage and husband and wife can act against it with the agreement of both parties.

(ii) Separate property is property brought by a husband and wife in marriage, and each husband and wife have the full right to do legal actions against it.

(iii) Property derived from gifts or inheritance obtained by each in marriage are under the control of each husband/wife.

(iv) The provisions of the property in the marriage are valid as long as the parties do not determine otherwise.

The phrase "as long as the parties do not determine otherwise" in Article 35 paragraph (2) pertains to the norms of marriage agreement stipulated in Article 29 of Law number 1 of 1974 concerning Marriage as follows:

Article 29

(1) "During or before the marriage takes place, the two parties with mutual agreement can enter a written agreement legalized by the marriage registrar employee, after which the contents also apply to third parties as long as the third party is included".

(2) "The agreement cannot be ratified if it violates the boundaries of law, religion, and morality".

(3) "The agreement is valid from the time the marriage takes place".

(4) "As long as the marriage takes place, the agreement cannot be changed, unless both parties agree to change it and the changes do not harm the third party".

Norms in Article 29 regulate exceptions to the norms of community property in Article 35 and Article 36 of Law number 1 of 1974 concerning Marriage by entering into marriage agreement. Marriage agreement is made at the time or before the marriage is held which is legalized by the marriage registrar employee. Marriage agreements take effect from the time the marriage takes place.

The norms in Article 37 of Law number of 1974 concerning Marriage regulate the distribution of community property if the marriage is terminated due to divorce; it is regulated according to their respective laws. The norm in Article 37 regulates that community property is limited if the marriage is terminated due to divorce. The previous norm in the Elucidation of Article 35 also affirmed that "if the marriage ends, then the community property is regulated according to their respective laws". Norms in Elucidation of Article 35 confirms that community property is divided if "marriage ends" so that the scope is wider. There are three reasons for marriages to end as Article 38 norms; i.e. because of "death, divorce, and court decisions". Therefore, the norm of community property is open for division, which is already stated in the Elucidation of Article 35 in conjunction with Article 38; i.e. if the marriage end. The end of marriage can be caused by death, divorce, and court decisions ${ }^{19}$.

Based on this description, the norm of community property in Law number 1 of 1974 concerning Marriage in Chapter VII which regulates "Property in Marriage" outlines the following matters:

- Classification of property in marriage which includes community property of husband and wife and separate property of each husband and wife;

- Authority or legal action against the property;

- Exceptions to the application of norms of property in marriage if the parties determine otherwise.

- The division of community property is carried out if the marriage ends, either because of "death, divorce, and court decisions".

- The way the division of community property is regulated according to each law.

\footnotetext{
${ }^{19}$ Abdul Rachmad Budiono, Peradilan Agama dan Hukum Islam di Indonesia (Judicial Religion and Islamic Law in Indonesia), (Malang: Bayumedia Publishing, 2003), page 73.
} 
The way to divide community property according to each law is as follows: first, it is carried out based on religious law, if the religious law is a living legal awareness in regulating the procedure for divorce; second, the rules for division are carried out according to customary law, if the law is a legal awareness that lives in certain community, and third, other laws ${ }^{20}$.

The norms of community property in Chapter VII which regulate "Property in Marriage" do not regulate community property in polygamous marriage. Therefore, further research is needed on the norms of community property in polygamous marriage.

\section{a. The Norms of Community Property in Polygamous Marriage}

Law number 1 of 1974 concerning Marriage adheres to the principle of monogamy ${ }^{21}$. However, it still provides an opportunity for a husband to marry more than a wife or is known as polygamous marriage. The norms of polygamous marriage are regulated in Chapter I "Basic Marriage" in Article 3, Article 4, and Article 5 of Law Number 1 of 1974 concerning Marriage as follows.

Article 3

(1) "Principally, in a marriage, a husband may only have a wife. A wife can only have a husband".

(2) "Courts can give permission to a husband to have more than one wife if the parties have desire to do so".

Article 4

(1) "In the event that a husband will have more than one wife, as stated in Article 3 paragraph (2) of this Law, he is obliged to submit a proposal to the Court in his area of residence".

(2) "The court referred to in paragraph (1) of this article only grants permission to a husband who will have more than one wife if":

a. "the wife cannot carry out her obligations as a wife";

b. "the wife has a disability or an incurable disease";

c. "wife cannot give offspring."

Article 5

(1) "To submit a proposal to the Court, as referred to in Article 4 paragraph (1) of this Law, the following are the conditions that must be met":

a. "the agreement from the wife/ wives"

b. "certainty that the husband is able to guarantee the needs of the lives of his wives and children"

c. "guarantee that husband will be fair to his wives and children".

(2) "The agreement referred to in paragraph (1) letter a of this Article is not needed for a husband if his wife/ wives cannot be asked for their consent and cannot be parties to the agreement, or if there is no news from his wife for at least 2 (two) years, or because of other reasons that need to be assessed by a Court Judge."

Based on this description, the norms of polygamous marriage in Article 3, Article 4, and Article 5 of Law number 1 of 1974 concerning Marriage regulate the following matters:

- Procedure for submitting polygamous marriage proposal to the Court;

- Reasons for being able to submit a polygamous marriage proposal; and

- Requirements to be able to carry out polygamous marriages;

\footnotetext{
${ }^{20}$ M. Yahya Harahap, Hukum Perkawinan Nasional (National Marriage Law), (Medan: CV Zahir Trading, 1975), page 125.

${ }^{21}$ The principle that requires that in a marriage a man may only do marriage with a wife and a wife may only do marriage with a man. General Explanation number 4 letter $\mathrm{c}$ of Law number 1 of 1974 concerning Marriage.
} 
The norm of community property in Chapter VII which regulates "Property in Marriage" as previously described does not regulate community property in polygamous marriage. Similarly, the norms of polygamous marriage in Article 3, Article 4, and Article 5 of Law number 1 of 1974 concerning Marriage also do not mention community property in polygamous marriages.

The norm of division of community property in polygamous marriages is found in "Chapter XIII Transitional Provisions" of Law number 1 of 1974 concerning Marriage in Article 65 as follows:

(1) "In the event that a husband has more than one wife either under the old law or under the law of Article 3 paragraph (2) of this Law, it applies the following provisions":

a. "Husbands must provide the same guarantee of life to all their wives and children";

b. "The second wife and so on do not have the rights to community property that existed before the marriage with the second or subsequent wife";

c. "All wives have equal rights to community property that has occurred since their respective marriages";

(2) "If the Court which grants permission to marry more than one person according to this Law does not determine otherwise, then the provisions of paragraph (1) of this article apply."

Norms of Article 65 paragraph (1) letter b and letter $\mathrm{c}$ of Law number 1 of 1974 concerning Marriage regulate the rights of each wife to community property in polygamous marriage. The norm of Article 65 paragraph (1) letter b regulates the right of the second wife and so on to community property that has occurred before their respective marriages. "The second wife and so on do not have the right to community property that existed before the marriage with the second or subsequent wife." Norms in Article 65 paragraph (1) letter c of Law number 1 of 1974 concerning Marriage regulates the rights of each wife for community property that "all wives have the same rights over community property that has occurred since their respective marriages."

\section{Wife Rights to Community Property in Marriage}

Before marriage, each man and woman have complete rights to their property. After binding themselves to a marriage institution, there are norms governing their rights to property ownership. The norms regarding wife's rights to community property are contained in Law number 1 of 1974 concerning Marriage.

The wife's right to community property in marriage can be traced to the norms of Article 35, Article 36, and Article 37 of Law number 1 of 1974 concerning Marriage which regulates property in marriage. Based on these norms, the wife's right to community property in marriage can be classified into 2 (two); i.e. namely the right to the community property section and the right to carry out legal actions on community property.

The norms that govern wife's rights to the community property section can be found in the following norms of Article 35:

(1) "Property acquired during marriage becomes community property".

(2) "The separate property of each husband and wife and the property acquired by each of them as gift or inheritance are under their respective control as long as the parties do not determine otherwise".

Law number 1 of 1974 concerning Marriage also regulates the rights and obligations of husband and or wife towards community property and separate property as formulated in the following Article 36:

(1) "Regarding community property, a husband or wife may act on the agreement of both parties".

The Rights of Each Wife in the Division of Community Property in Polygamous Marriage According to Law Number 1 of 1974 Concer ning 
(2) "Regarding separate property from husband and wife, each has the full right to carry out legal actions regarding his/her own property".

According to these norms, property in marriage is known by several categories; i.e. community property, separate property, and property derived from gifts or inheritance. Each party has the full right to carry out legal actions against separate property and property derived from gifts or inheritance. Therefore, this property is not included in the category of community property. In the case of community property, parties who can do legal actions against community property are husband and wife. One party cannot leave the other party to carry out legal actions regarding community property in marriage, because their position is balanced; as a joint owner of community property.

Property problems in marriage also often arise from debt problems. Debt in marriage can be divided into personal debt (prive debt) and mutual debt (gemeenschap debt), which is debt for mutual needs ${ }^{22}$. The personal debt of the husband or wife is their personal obligation to repay, while the mutual debt is a mutual obligation. Legal actions on community property carried out by the husband or wife must be known to others, because they result in illegal legal actions. The Supreme Court of Indonesia had encountered cases of community property use without the knowledge of the husband/ wife. In this case, a husband sold land that is a community property without his wife's consent. Finally, based on Decision number Reg. 269 PK/Rev./1996 stated that "actions against community property by husband or wife must be approved by husband and wife. Since there was no wife's agreement, the actions of a husband who makes an agreement on community property (land) are illegal."

Legal actions to enter into agreements relating to community property made without the consent of the spouse are deemed to be legally flawed. Such an agreement is made without the consent of the husband or wife so that the terms of the agreement are not fulfilled as stipulated in Article 1320 of the Civil Code concerning halal causes. Meanwhile, Article 36 paragraph (1) of Law number 1 of 1974 concerning Marriage has determined the use of community property to be carried out by a husband and wife on the basis of the agreement of both parties. If it is interpreted in a contrario, Article 36 paragraph (1) of Law number 1 of 1974 concerning Marriage prohibits the use of community property without the consent of a married couple.

\section{Each Wife's Rights to the Division of Community Property in Polygamous Marriage}

Property acquired by husband and wife during marriage is a community property ${ }^{23}$. If the marriage ends because of death or divorce, then the husband and wife each have the right to the community property they obtain ${ }^{24}$. Law number 1 of 1974 concerning Marriage regulates the rights of each wife to the distribution of polygamy marriage property in Article 65 paragraph (1) letter b and letter c. Therefore, this discussion will classify it into two sub-divisions: the wife's right to community property in polygamous marriage according to Article 65 paragraph (1) letter $\mathrm{b}$ and the wife's right to community property in polygamous marriage according to Article 65 paragraph (1) letter c.

\section{Implementation of Distributive Justice in the Division of Community Property in Polygamous Marriage}

To realize justice and legal protection in polygamous marriages, community property is not necessarily determined based on aspects of the acquisition time of community property, but it also needs to be studied from several aspects, including "the aspect of the origin of the realization of community property". Community property in a marriage is realized by the efforts of a husband and wife, but it can

\footnotetext{
${ }^{22}$ Subekti, Pokok-Pokok Hukum Perdata (Principles of Civil Law), (Jakarta: Intermasa, 2005), page 34.

${ }^{23}$ Article 37 of Law number 1 of 1974 concerning Marriage.

${ }^{24}$ Article 35 in conjunction with article 37 of Law number 1 of 1974 concerning Marriage.
} 
also come from the inheritance or gift of each husband and wife which is manifested into property in marriage. Determination of community property in polygamous marriages is only based on marriage, each wife can ignore the rights of another wife. To realize justice and legal protection in the division of polygamous marital community property, it does not necessarily give equal rights to all wives, but it needs to be seen more deeply about community property in polygamous marriages from several aspects, including "the aspect of the time of the legal relationship between a husband and his wives". From the aspect of the legal relationship between a husband and wives, the division of polygamous marriage property that gives equal rights to all wives will lead to injustice and neglect the protection of the wife who had previously married. In accordance with the elaboration of the implementation of the norm stated by M. Yahya Harahap, a husband who died leaving three wives; i.e. wife A, wife B, and wife $\mathrm{C}$, then the rights to community property since each marriage are: $1 / 2$ part for wife $A, 1 / 2$ part for wife $B$, and $1 / 2$ part for wife $\mathrm{C}$, while part for husband is $1 / 2+1 / 2+1 / 2$.

The division of property by giving $1 / 2$ part portion to the wife is the norm for the division of community property in the marriage of a husband with one wife or monogamy. However, if there are more than one wife, then such implementation will cause injustice and ignore the protection of the wife. When a husband marries a second wife, the relationship between the marriage law and the first wife does not end, so since then the husband has two women who are bound in marriage. The implication is that the property obtained from the marriage with the second wife is also the first wife's community property.

The rights arising from marriage can be seen from the aspect of the time a legal relationship occurs. Based on the legal relationship that occurs earlier, the first wife and subsequent wife have the right to community property obtained from the husband's marriage to the last wife. On the contrary, regarding the husband's community property with the first wife, "the second wife and so on are not entitled to the community property". Likewise, community property obtained by a husband with a second wife, then the third wife and "so on do not have the right to the community property". Thus, it applies to the next wife. To be more precise in understanding the implementation of the norms of Article 65 paragraph (1) letter c, it is presented in the following chart.

Chart 1 Implementation of Norms in Article 65 paragraph (1) letter c Based on Distributive Justice

Part of each wife for community property by paying attention to "the aspect of the time of the legal relationship between a husband and his wives"

\begin{tabular}{|c|c|c|c|c|}
\hline I & Husband-Wife1 & & & \\
\hline II & Huchand-INifo1 & H-(N/fo1_-MNifo) & & \\
\hline III & Husband-Wife1 & H-Wife1-Wife2 & H-Wf1-Wf2-Wf3 & \\
\hline VI & Husband-Wife1 & H-Wife1-Wife2 & H-Wf1-Wf2-Wf3 & H-Wf1-Wf2-Wf3-Wf4-etc \\
\hline & $\begin{array}{l}\text { cription: } \\
\text { - } \text { Part of the } \\
\text { - When mar } \\
\text { has been o } \\
\text { husband, } \mathrm{f} \\
\text { - When mar } \\
\text { been obtai } \\
\text { husband, } \mathrm{f}\end{array}$ & $\begin{array}{l}\text { amunity prop } \\
\text { with the sec } \\
\text { ned since ma } \\
\text { wife, and sec } \\
\text { e with the thi } \\
\text { since marrias } \\
\text { wife, second }\end{array}$ & $\begin{array}{l}\text { first husband } \\
\text { ife occurs, co } \\
\text { with the secor } \\
\text { ife. } \\
\text { e occurs, com } \\
\text { the third wif } \\
\text { and third wife, }\end{array}$ & $\begin{array}{l}\text { wife is half. } \\
\text { inity property, which } \\
\text { ife, is the right of the } \\
\text { ty property, which has } \\
\text { comes the right of the } \\
\text { so on. }\end{array}$ \\
\hline
\end{tabular}

Source: The results of the author's analysis of the implementation of norms in Article 65 paragraph (1) c Law number 1 of 1974 concerning Marriage in accordance with distributive justice, constructed by the author, in 2018 . 
By paying attention to the aspect of the time of the occurrence of legal relations, it will have implications for the determination of the part which is the right of each wife over the community property. The part of each wife in polygamous marriages is not necessarily the same. The division of community property has occurred since marriage ended because of divorce or death. In the event that the marriage ends with one wife, it will open the division of community property to another wife.

The norm for the distribution of polygamy marriage property communities is determined as follows ${ }^{25}$ :

(1) "Community property, from the marriage of a husband who has more than one wife, is respectively separate and independent".

(2) "Ownership of community property from the marriage of a husband who has more than one wife as mentioned in paragraph (1), is calculated at the time of the second, third, or fourth marriage contract".

Looking at the norms in paragraph (2), the determination of the right to community property in certain circumstances can cause harm to the wife who marries first, so that the norms in the article contain injustice. The property obtained during the marriage of the husband and first wife are the community property of the first husband and wife. The property acquired during the marriage of the husband with the second wife and at that time were also tied to marriage with the first wife, then the property became the community property of the husband, first wife, and second wife. It applies similarly if the husband marries the next wife. If it is consistent with the logic of thinking, the part of each wife is not the same. If a polygamous marriage ends due to a divorce from the first wife, then the logical interpretation is as follows: the first wife gets $1 / 2$ (half) part of community property with her husband, plus $1 / 3$ (one third) of property obtained by the husband and first wife, plus $1 / 4$ (quarter) of property obtained by the husband with the first, second and third wives, plus $1 / 5$ (one fifth) of community property obtained by the husband with the first, second, third, and fourth wives. For more details, the following sections will be described for each wife for community property in polygamous marriage as in the following table.

Table 1 Parts of Each Wife in the Division of Community Property in Polygamous Marriage in accordance with Distributive Justice

\begin{tabular}{lllll}
\hline Husband & First Wife & Second Wife & Third Wife & Fourth Wife \\
\hline $1 / 2$ & $1 / 2$ & & & \\
$1 / 3$ & $1 / 3$ & $1 / 3$ & & \\
$1 / 4$ & $1 / 4$ & $1 / 4$ & $1 / 4$ & \\
$1 / 5$ & $1 / 5$ & $1 / 5$ & $1 / 5$ & $1 / 5$ \\
\hline
\end{tabular}

Source: The results of the author's analysis of the implementation of norms in Article 65 paragraph (1) c of Law number 1 of 1974 concerning Marriage in accordance with distributive justice, constructed by the author, in 2018

\section{Conclusion}

A man and woman, before marriage, each has the full right to his/her property. After binding themselves to a marriage institution, there are norms that regulate the rights to ownership of their property. The norm for the division of polygamous marriage property in Article 65 paragraph (1) letter c of Law number 1 of 1974 concerning Marriage confirms that "all wives have the same rights over community property that has occurred since their respective marriages" which can be explained as follows:

- all wives have the right to polygamous marriage property; however, the rights of each wife are not the same. The part that is the right of each wife over the polygamous marriage property community is determined by the time the husband has a legal relationship with each wife;

${ }^{25}$ Article 94 Compilation of Islamic Law 
- rights to the community property of the husband and first wife are property that have been obtained before the husband carries out the second marriage; each part is half.

- since marriage with the second wife occurs, community property that has been obtained before the husband carries out the third marriage is the right of the husband, first wife, and second wife, each part is one third;

- since marriage with the third wife occurs, community property that has been obtained before the husband carries out the fourth marriage is the right of the husband, first wife, second wife, and third wife, each part is a quarter; and

- since marriage with the fourth wife occurs, community property that has been obtained is the right of the husband, first wife, second wife, third wife, and fourth wife, each part is one fifth.

\section{Conclusion}

From the results obtained from this study, we can know that the preparation of well-organized and structured training models can significantly improve the individual abilities of players. In addition, a neatly arranged exercise model will make it easier for trainers to make training programs in the short and long term. In making practice models, it is recommended to multiply the game elements, it aims to reduce the boredom of the players during the exercise.

Suggestions for futsal trainers are expected to be able to make more training models so that they can be used as a joint reference in improving futsal, especially in regions, schools, universities and even national circles.

\section{References}

Law number 12 of 2011 concerning Establishment of Legislation (State Gazette of the Republic of Indonesia of 2011 number 82, supplement to the State Gazette of the Republic of Indonesia number 5234).

Law number 48 of 2009 concerning Judicial Power (State Gazette of the Republic of Indonesia of 2009 number 157, supplement to the State Gazette of the Republic of Indonesia number 5076).

Law number 7 of 1989 concerning the Religious Courts (State Gazette of the Republic of Indonesia of 1989 number 73, supplement to the State Gazette of the Republic of Indonesia number 3316).

Law number 3 of 2006 concerning changes to Law number 7 of 1989 concerning Religious Courts (State Gazette of the Republic of Indonesia of 2006 number 22, supplement to the State Gazette of the Republic of Indonesia number 4461).

Law number 50 of 2009 concerning the second changes to Law number 7 of 1989 concerning Religious Courts (State Gazette of the Republic of Indonesia of 2009 number 159, supplement to the State Gazette of the Republic of Indonesia number 5078).

Law number 1 of 1974 concerning Marriage (State Gazette of the Republic of Indonesia of 1974 number 1, supplement to the State Gazette of the Republic of Indonesia number 3019). 
Government Regulation number 9 of 1975 concerning Implementation of Law number 1 of 1974 (State Gazette of the Republic of Indonesia of 1975 number 12, supplement to the State Gazette of the Republic of Indonesia number 3050).

\section{Copyrights}

Copyright for this article is retained by the author(s), with first publication rights granted to the journal.

This is an open-access article distributed under the terms and conditions of the Creative Commons Attribution license (http://creativecommons.org/licenses/by/4.0/). 